\title{
Chinese Immigrant Parents' Involvement in Their Children's School Education: High Interest but Low Action
}

\author{
Lan Zhong \\ University of Windsor \\ George Zhou \\ University of Windsor
}

\begin{abstract}
Using interview as the primary data collection method, this qualitative study examined how Chinese immigrant parents are involved in their children's school education and what factors shape the formats of their involvement. Twelve Chinese immigrant families participated in this study. Data analysis reveals that Chinese parents got involved in their children's school education regardless of personal experiences. They expressed beliefs that parental involvement is beneficial to both the school and children. However, generally speaking, participants did not go to their children's school without teachers' invitation. Language barrier, lack of time and energy, and unfamiliarity with the Canadian school culture were stated as the main reasons that contributed to participants' limited involvement in school activities. Particularly, new immigrants often feel intimidated to talk to teachers since they do not know what they can say and what not given their unfamiliarity with the Canadian school culture.
\end{abstract}

Keywords: School involvement, Chinese immigrant parents, culture

Lan Zhong recently graduated with a PhD from the Faculty of Education, University of Windsor. He taught courses in Chinese culture and English language art. Her research focuses on immigrant education and teaching English as a second language. Email: zhongl@uwindsor.ca

George Zhou is an Associate Professor at the Faculty of Education, University of Windsor, where he teaches undergraduate and graduate courses in science education and research methods. His research interests cover science education, technology and teacher education, immigrant education, and international and comparative education. Email: gzhou@uwindsor.ca

Brock Education, Volume 20, No. 2, Spring 2011, 4-21 


\section{Introduction}

Over the last three decades, researchers have conducted studies of the impacts of parental involvement in children's education (Brough \& Irvin, 2001; Epstein, 1995; Taylor \& Lopez, 2005; Zellman \& Waterman, 1998). These studies have documented that effective parental involvement leads to students earning higher grades and test scores (Fan \& Chen, 2001; Jeynes, 2007), reducing the achievement gap between high and low performing students (Lee \& Bowen, 2006), and increasing positive behaviour and emotional development of children (Sheldon \& Epstein, 2001; Taub, 2008). Parents' socio-demographic factors such as family income, occupational status, educational level, and relationships influence the ways they get involved in their children's education (Coleman, 1998; Entwisle \& Alexander, 1995; Perna, 2004). Among the array of parental involvement activities, some have high influences on students' learning achievements, motivation, or school engagement, while the others has low impacts (Desforges, \& Abouchaar, 2003; Ho \& Willms, 1996). Particularly, the type of parental involvement and the context of involvement can generate different impacts on students' school achievement and behaviours (Jeynes, 2005a; McNeal, 1999; Steinberg, Lamborn, Dornbusch, \& Darling, 1992).

Within the past two decades, there has been a rapid growth of Chinese immigration in Canada. For example, from 2001 to 2006, there were over 466,940 Chinese changed their home residence from China to Canada. Chinese have become the second largest immigrant population in Canada (Statistics Canada, 2006). Due to the Canadian immigrant policy, most recent Chinese immigrants were highly educated professionals and financially independent before they moved to Canada (Guo \& DeVoretz, 2006). The study of how Chinese immigrant parents get involved in their children's education in Canada becomes an important and timely research topic.

Research has suggested that parents from different ethnic and cultural backgrounds may view and interpret the meaning of parental school involvement differently (Jeynes, 2005b; Juang \& Silbereisen, 2002; Mau, 1997). For instance, some cultures view it as rude for a parent to intrude into the life of the school and the parents from these cultures prefer to get involved in their children's education at home (Balli, Demo, \& Wedman, 1998). In contrast, parents from other cultures may spend much time in their children's school because their cultures encourage establishing a closer parent-school relationship (Hill \& Taylor, 2004).

Chinese usually see education as the most important means to acquire personal advancement, high social status, wealth, respect, etc. Particularly, they place great emphasis on academic achievement as a means to achieve such social mobility (Dyson, 2001; Li, 2001; Zhou, 2000). This value about education is carried into their new places of residence. They do not only actively re-educate themselves, but also hold high expectations of their children's education. Kao (1995) indicates that Asian parents promote high levels of educational attainment for their children to compensate for the anticipated discrimination in the job market.

With high expectations of their children's education, Chinese immigrants often get actively involved in their children's schooling. It is well known that Chinese parents assign extra homework to their children and register them in many after-school programs ( $\mathrm{Li}, 2001$; Louie, 2001; Siu, 1994). However, less is known about how they are involved in the school-based activities. Studies of Latin American immigrants' education involvement have shown that immigrant parents often get less involved in school-based activities and such less school involvement could be mistaken as lack of interest in their children's academic work (Commins, 1992). We assume that this finding is applicable to Chinese immigrants as well, given some of 
the common challenges shared by all immigrants, such as language inefficiency and cultural conflicts.

Over the last few years, we have been conducting a comprehensive study to examine how Chinese immigrant parents get involved in their children's education, home-based and school based. The demographic, social, language and cultural factors were explored for an understanding of how these factors shape the ways of Chinese immigrant parents' involvement. This paper only reports the findings regarding their school-based involvement. Findings are believed to be beneficial for the school administrators and teachers to develop better communication with immigrant parents.

\section{Theoretical Framework}

This study employs the sociocultural theory as its theoretical framework. Sociocultural theorists argue that human development is essentially social, deriving from human social relations and situated in interpersonal, socio-historical as well as sociocultural contexts (Rogoff, 2003; Rogoff \& Angelillo, 2002; Wertsch \& Kanner, 1992). A key feature of the sociocultural approach is an examination of human development that is based on not only the qualities that reside within an individual, but also the social interactions in broader social and cultural contexts.

Sociocultural contexts affect human development at an interpersonal level through faceto-face interactions and at a sociocultural level through participation in cultural activities. JohnSteiner and Mahn (1996) state that human activities take place in cultural contexts, are mediated by language and other symbol systems, and can be best understood when investigated with regard to their historical contexts. Also, different social and cultural contexts create and reflect different outcomes in terms of human behaviour (Rogoff, 1990, 2003; Vygotsky, 1987; Wertsch \& Kanner, 1992).

This study explores the ways and perspectives of Chinese immigrants' parental involvement in their children's school education in Canada. Although the focus of study is not on the topic of human development from young age to adult, the process of immigrants' adaption from one culture to another is assumed to share a similar process of growth. From a sociocultural perspective, this study involves examining parents' perspectives and behaviours of school involvement in their immediate environment and their interaction with the larger environment as well.

Sociocultural theorists examine what kind of social practices provide the proper context for the development of the human mind and how human beings construct contexts (Li, 2001). The sociocultural theory is helpful in better understanding how Chinese immigrant parents construct their parental practices based on their previous experiences, original cultural values, a new cultural context, as well as how they pass on their cultural values through parenting.

Modifying the original model of parental involvement proposed by Hoover-Dempsey and Sandler (1995 \& 1997), Walker, Wilkins, Dallaire, Sandler, and Hoover-Dempsey (2005) portray parental involvement in two terms: school-based and home-based. They explain parents' involvement decisions from three psychological aspects: (a) parents' motivational beliefs, (b) parents' perceptions of invitations for involvement from others, and (c) parents' perceived life context. Parents' motivational beliefs are defined as their self-constructed role and self-efficacy for getting involved in their children's education. Parents' perceptions of invitations for involvement from others entail their perceptions of the general invitation for involvement from the school and the specific invitation from the teacher and children. Parents' perceived life 
context refers to their beliefs about whether they have the time, energy, skills and knowledge to get involved in children's education.

Walker et al.'s model was developed largely from the studies of mainstream parents. Compared with these parents, immigrant parents have a unique social and cultural context. Chinese parents face various challenges due to the discontinuity they experienced in multiple areas, including language, cultural values, job availability, and different social and education systems. Their original cultural values, education backgrounds, financial resources, ability to cope with the challenges will exert influence on any one of the three psychological constructs and consequently impact their involvement in children's education. Past studies have actually provided some evidence for this impact (Jeynes, 2003; Li, 2005; Siu, 1994; Sputa \& Paulson, 1995). Regardless of socioeconomic level, Chinese American parents are more likely than European parents to spend time helping their children in their homes (Kao \& Tienda, 1998). Li (2005) and Siu (1994) pointed out that Asian immigrants tend to be more involved in their children's education outside school than in school.

\section{Methodology}

The study was conducted in the city of Windsor, Ontario, which is the fourth most ethnoculturally diverse city in Canada (Statistics Canada, 2006). With a relatively mild winter, the opportunities to commute to the United States, low costs of living, and the existence of a large Chinese community, Windsor has attracted an increasing number of Chinese immigrants. Since Chinese children have appeared on almost all school campuses in Windsor, the region becomes a significant location for the studies of Chinese parents' school involvement.

The nature of this study is qualitative, using interview as the main data collection method. Strauss and Corbin (1990) define the qualitative research as "any kind of research that produces findings not arrived at by means of statistical procedures or other means of quantification" ( $p$. 17). Qualitative research is interested in the process and meaning of experience rather than outcome (Creswell, 2007). It attends to the rich descriptions that emerge from a participant's cultural context and helps the researchers understand people and sociocultural contexts within which they live (Creswell, 2008). It also benefits researchers to gather in-depth data by asking questions and listening to participants' descriptions in their own language and on their own terms in an authentic world (Patton, 2002).

\section{Participants}

Twelve Chinese immigrant couples participated in this study. They were selected on a voluntary basis. All participants are from mainland China and had at least one child attending elementary schools when the study took place. The rationale for selecting participants from Mainland China is because it has taken over Hong Kong and Taiwan as the largest single source of Chinese immigrants to Canada since 1997, and this trend has continued to today (Citizenship and Immigration Canada, 2002). The major reason we chose parents of elementary school age children was because research indicates that those at the high school level tend to get less involved in their children's schooling or are not found to be as participatory (Adams \& Christenson, 2000; Grolnick, Kurowski, Dunlap, \& Hevey, 2000; Simon, 2004). In addition, we selected participants from those Chinese couples who have at least one work income and intentionally excluded those families with no work income. The families without work income 
normally come to Canada with financial resources, which pull their adaptation process off the main track of most Chinese immigrants' acculturation.

\section{Data Collection}

Rubin and Rubin (1995) stated that the researcher using qualitative interviewing is "not looking for principles that are true all the time and in all conditions, like laws of physics; rather the goal is understanding of specific circumstances how and why things actually happen in a complex world" (p. 38). Typically, the researcher develops a set of related questions geared toward discovering what people behave, think and feel, how they account for their experiences and actions, and what opportunities and obstacles they face (Berg, 2007; Denzin \& Lincoln, 2000).

Semi-structured interview was used to collect data in this study. A set of open-ended questions were developed to collect self-reported information about participants' experiences with, perspectives of, and expectations about their involvement in children's school education. Particularly, the challenges and confusions they have in their attempt to get involvement in school education were explored. In addition, demographic data were collected as well. This semi-structured interview provides enough room for participants to interpret questions asked and express their general views or opinions in more detail, and meanwhile allows the researchers to maintain some control over the flow of the topics (Berg, 2007).

Participants were interviewed in pairs. In other words, both parents from one family were interviewed together. Interview locations were chosen based on the convenience and comfort of the participants. Participants were informed that they could choose to be interviewed either in English or Mandarin. All participants chose Mandarin since it is the mother tongue of the participants and researchers. This assured an effective and accurate communication between the researchers and participants.

Most interviews lasted approximately 60 to 90 minutes and were audio recorded. However, two couples felt uncomfortable to have their voices recorded. Each of their interviews took about two hours so that the researchers had time to note down their responses. Primary data analysis began "immediately after completing the first interview" (Maxwell, 2004, p. 77) so that the following interviews could be informed by what was learned from previous ones regarding what questions were asked and in what ways they were asked. The themes in early interviews could be clarified with more probing in later interviews.

Field notes were regularly taken during the research process to record the details about interviewees, interview time and location. Participants' gestures and specific expressions that the tape recorders could not catch were noted down. These field notes served as a reminder for the researchers to recall what happened in the interview when transcribing and analyzing the interview recordings. Some information revealed from informal dialogues before or after the interview was recorded in field notes as well, which provides additional data beyond the tape recording.

\section{Data Analysis}

After each interview, the researchers listened and transcribed the recording if time permitted. Follow up phone calls were made within one week of the completion of the face-to-face interview to check if participants had any information they wanted to add or to ask them to 
elaborate on some points they talked about during the interview. The interview notes of those two non-recorded interviews were compiled and sent to the participants to confirm the accuracy.

The final data analysis took a common procedure suggested by Creswell (2008). First, the researchers read the twelve interview manuscripts in their entirety several times to obtain a general sense of the data. Each manuscript was coded by marking the statements relevant to the study topic and grouping these statements in preliminary ways. Each statement was treated equally in this phase of the data analysis. Second, statements which were overlapping, repetitive, and vague were eliminated. The statements that remained were then re-coded as the invariant constituents. Third, the invariant constituents were clustered into thematic labels. In the process of data coding, a constant comparative analysis was used (Schwantdt, 2001). It involved taking one piece of data and comparing it with all others that might be similar or different in order to develop assumptions about the possible relationships among various pieces of data.

Interviews were transcribed and analysed in Mandarin. Certain parts of transcripts were translated into English later when these were used for quotations. The data analysis was cross checked by at least two researchers who are proficient in both English and Mandarin.

\section{Findings}

\section{Participants' Demographics}

Table 1 presents the background information of the twelve participating families at the time of data collection. It includes parents' education, occupation in China and Canada, years of residence in Canada, and their children's information. Six of the twelve families had one child and the other six had two children. For the families with one child, one family had a son and five a daughter. Among the six families with two children, four families had one son and one daughter and two families had two sons. The majority of the families were highly educated professionals. Except for one mother who had a college diploma, the rest of the parents had received university degrees before they came to Canada. At the time of data collection, four parents had obtained a doctoral degree, eight a master's degree, and two a bachelor degree from Canadian universities. One father was going to finish his master's degree and two mothers a bachelor degree from Canadian universities. Seven parents did not pursue a Canadian degree. Seven families had resided in Canada for more than ten years and five families less than five years. For the convenience of reporting, we use FF1 referring to the father from family one, and MF1 the mother from family one. Such abbreviation goes through the 12 families.

Table 1

Background Information of the Twelve Families

\begin{tabular}{|l|l|l|l|l|c|}
\hline Participants & \multirow{2}{*}{ Education } & Occupation & \multirow{2}{*}{$\begin{array}{c}\text { Years in } \\
\text { Canada }\end{array}$} \\
\cline { 4 - 5 } & & China & Canada & \multirow{1}{*}{13} \\
\hline \multirow{4}{*}{ Family 1} & Father & Ph.D. $*$ & Science Researcher & Mechanical Engineer & \\
\cline { 2 - 5 } & Mother & B.Sc. & System Engineer & Home-maker & \\
\cline { 2 - 5 } & Son & Grade 2 & & & \\
\cline { 2 - 5 } & Daughter & Sophomore & & & \\
\hline
\end{tabular}

Brock Education, 20(2), 4-24 


\begin{tabular}{|c|c|c|c|c|c|}
\hline \multirow[t]{3}{*}{ Family 2} & Father & B.Sc. & Engineer \& Manager & Labour worker & \multirow[t]{3}{*}{4} \\
\hline & Mother & $\begin{array}{l}\text { B.Sc.* } \\
\text { (finishing) }\end{array}$ & Accountant & University student & \\
\hline & Son & Grade 1 & & & \\
\hline \multirow[t]{3}{*}{ Family 3} & Father & M.D.* & Software engineer & Technician & \multirow[t]{3}{*}{4} \\
\hline & Mother & $\begin{array}{l}\text { B.Sc.* } \\
\text { (finishing) }\end{array}$ & Software engineer & University student & \\
\hline & Daughter & Grade 3 & & & \\
\hline \multirow[t]{4}{*}{ Family 4} & Father & Ph.D.* & Professor & Electrical engineer & \multirow[t]{4}{*}{15} \\
\hline & Mother & M.D.* & Professor & Mechanical engineer & \\
\hline & Son & Grade 4 & & & \\
\hline & Son & Grade 11 & & & \\
\hline \multirow[t]{3}{*}{ Family 5} & Father & $\mathrm{MBA} *$ & Department Manager & Labour worker & \multirow[t]{3}{*}{3} \\
\hline & Mother & $\begin{array}{l}\text { College } \\
\text { diploma }\end{array}$ & Technician & Labour worker & \\
\hline & Daughter & Grade 7 & & & \\
\hline \multirow[t]{4}{*}{ Family 6} & Father & M.D.* & Science researcher & Computer Engineer & \multirow[t]{4}{*}{14} \\
\hline & Mother & M.D.* & Science researcher & Accountant & \\
\hline & First Son & Grade 4 & & & \\
\hline & $\begin{array}{l}\text { Second } \\
\text { Son } \\
\end{array}$ & Grade 11 & & & \\
\hline \multirow[t]{3}{*}{ Family 7} & Father & B.A. & Businessman & Self-employed & \multirow[t]{3}{*}{13} \\
\hline & Mother & M.D. & Medical doctor & Massage therapist & \\
\hline & Daughter & Grade 7 & & & \\
\hline \multirow[t]{4}{*}{ Family 8} & Father & M.D.* & Professor & Computer Engineer & \multirow[t]{4}{*}{4.5} \\
\hline & Mother & M.D.* & Journalist & Home-maker & \\
\hline & Son & Kindergarten & & & \\
\hline & Daughter & Grade 5 & & & \\
\hline \multirow[t]{4}{*}{ Family 9} & Father & Ph.D.* & Scientific Researcher & Computer Engineer & \multirow[t]{4}{*}{14} \\
\hline & Mother & B.Sc.* & Medical Doctor & $\begin{array}{l}\text { Public health } \\
\text { consultant }\end{array}$ & \\
\hline & Daughter & Grade 3 & & & \\
\hline & Son & Freshman & & & \\
\hline \multirow[t]{3}{*}{ Family 10} & Father & $\begin{array}{l}\text { M.B.A. * } \\
\text { (finishing) }\end{array}$ & Marketing manager & College student & \multirow[t]{3}{*}{3} \\
\hline & Mother & B.A. & Interpreter & Self-employed & \\
\hline & Daughter & Grade 6 & & & \\
\hline \multirow{3}{*}{ Family 11} & Father & B.Sc. & Computer Engineer & Mechanist & \multirow[t]{3}{*}{11} \\
\hline & Mother & B.Sc.* & Librarian & $\begin{array}{l}\text { Learning Commons } \\
\text { Specialist }\end{array}$ & \\
\hline & Daughter & Grade 7 & & & \\
\hline
\end{tabular}

Brock Education, 20(2), 4-24 


\begin{tabular}{|l|l|l|l|l|l|}
\hline Family 12 & Father & M.D.* & Editor & Home-maker & \multirow{2}{*}{13} \\
\cline { 2 - 5 } & Mother & Ph.D.* & Professor & Professor \\
\cline { 2 - 5 } & Son & Grade 3 & & & \\
\cline { 2 - 5 } & Daughter & Freshman & & & \\
\hline
\end{tabular}

Note: $*$ =degree obtained in Canada

\section{School-based Involvement}

Responding to the question about their perspectives on school involvement, all participants expressed a belief that school involvement is positively associated with their children's educational development. They listed the following potential benefits of parental involvement: (1) parents get information about their children's academic performance and behaviours at school; (2) parents and teachers know the expectations of each other; (3) parents have a chance to meet other parents and share experience in educating their children. By gaining this information, they can provide better help to their children. For instance, when asked about the connection between parental involvement in school activities and their child's development, MF12 said, "Through attending school activities, we know our child's school performance and know what is going on in the school. Thus, we can offer better help for our child's development." MF9 stated, "I like to talk with other parents when I meet them in school. I talk to them about how they educate their children. I also get more information about the school by talking with them." The types of school involvement participants reported included parent-teacher conference, fundraising, attending school performances, volunteering, and sitting on the parent council.

Parent-teacher conference. All participants reported that they attended parent-teacher meetings regardless of whether or not language was a barrier. MF5 stated that her English was not good, but she still attended the conference with her husband: "Although my English in not good, I like to go, sitting beside my husband. I want to know all the information about my daughter instead of staying home waiting for a report from my husband." Some time, both parents went to the meeting together. Other times, only one parent had time to go to the meeting. For instance, MF9 said, "My husband and I tried to arrange the time to attend the parent-teacher conference together. However, most of the time, I attend this conference on my own since my husband is too busy."

The number one topic that parents often asked about during the parent-teacher conference was their children's academic achievement. For instance, MF8 responded, "I asked about my daughter's academic performances in school, her weaknesses and strengths in each subject. I asked for teachers' suggestions about how I can assist her at home." Similarly, MF9 said:

I asked the teacher about my daughter' academic achievement such as whether she likes to ask questions in class, whether she is actively involved in group work, what kind of things I can do to help my daughter's academic development at home, and so on.

The academic emphasis was particularly strong for recently arrived families (F2, F3, F5, F8, and F10). For instance, MF2 has been in Canada for 4 years. She remarked, "I always ask my 
daughter`s academics. Academic is the most important thing for school children." MF3 has been in Canada for 4 years. She said:

I asked the teacher about whether my daughter could catch up with her peers in academics, and whether she had any language difficulty in school. When we moved to Canada, she had finished the grade 3 in China. My English is not good, so I am concerned about my daughter's language proficiency.

Besides academic achievement, parents who arrived in Canada earlier also asked about their children's social and moral behaviours such as whether their children follow the school rules, respect teachers, and get along well with other students. For instance, MF4, who had resided in Canada for 15 years, said, "In addition to asking my son's performance in academics, I also ask whether my son respects teachers, whether he follows school rules, and whether he is getting along with other children." These parents were found to be more concerned of school events as well. For instance, family 1 arrived in Canada over thirteen years prior to the study. FF1 said:

We also want to know what and when school events are going to take place, such as children's show, swimming competition, and fundraising. When I get this information, I can arrange time and try to attend these activities, or my wife can take part in these activities according to her availability.

Family 6 has been in Canada for 14 years. MF6 said:

I am not concerned much about my son's academics because the teacher always tells me that my son is doing very well. He always gets A's. Beside academics, I also want to know what is happening or what is going on in the school so that I can manage to positively get involved in these activities. As well, I can give my child some instructions.

Fundraising. Parents actively supported their children to participate in different types of fundraising activities. Some parents encouraged their children to sell chocolates in the community for their schools. Others cooked food at home and let their children sell it to get money for the school. MF8, a home-maker, said, "I learnt from other parents how to bake cookies. My daughter brought cookies I made to school and sold them to her schoolmates. Then, she gave the money to the school." FF7 said, "Sometimes, my daughter brings home book orders. I usually buy some for my daughter [so that the school can get some money from my order]."

Parents believed that fundraising contributes to the school and would like to take part in these activities when they were able to. FF9 remarked, "The public schools in China do not ask parents to raise fund to support school projects. However, since my child's school here expects and encourages parents and children to raise fund and [I believe] it is good for the school, we do our best to support this activity."

Some parents stated that participation in fundraising activities does not only benefit the school but also benefits children's social skills. For instance, FF3 expressed his view on fundraising: 
To get involved in school fundraising does not only benefit the school, but also the child. To raise fund, children are some time required to sell chocolates. We drive her and stand far away to watch and guard her. I watch her knocking at the doors and communicated with people either our friends or strangers to sell the chocolate. My daughter is very shy. This activity helps her develop social skills.

Attending children's school performance. The majority of parents, ten out of the twelve families, remarked that they usually attended their children's school performances like school concerts and sport meetings. FF1 narrated his experience of attending a Christmas celebration: "My wife and I attended his Christmas performance last year. While my son was singing and dancing with his peers on the stage, we were so proud of him. I recorded his fabulous performance into a video." MF9 said, "My husband and I would go together to attend my daughter's shows in school. If my husband is too busy, I will go to the show myself."

Parents remarked that to attend children's performance is a way to express how much they care and support their children. They believed that children will have a sense of success when they know that their parents are present in their performance, as MF11 stated:

A child needs support and encouragement from parents. When my husband and I took part in my daughter's performance, my daughter was very happy and excited. She even drew a picture, which depicted a mother and father watching their daughter's show in school. This picture was put up on her classroom wall by the teacher.

Fieldtrips. In terms of fieldtrips, two mothers (MF1 and MF8) and one father (FF12), who were homemakers, stated that sometimes they assisted the school teacher to monitor students in fieldtrips. MF8 said, "I don't work, so I go to field trips. I feel good that I can do something for the school." MF1 perceived that her English proficiency was not good enough to communicate with native English speakers, but she would like to volunteer herself as a fieldtrip assistant if there were some Chinese children in a fieldtrip. FF12 remarked, "Voluntary work makes me have a good sense that I could contribute to the school."

Parent council. Among the 12 families, only two mothers (MF4 and MF12) reported that they were members of parent council. In regards of her understanding of parent council, MF4 remarked:

The parent council aims to involve parents into a school's decision-making process. Through the parent council, parents can voice their opinions about school issues and contribute to the on-going school plans and events... By being a parent council member and attending its monthly meeting, I get to know what the school is going to do and provide my opinions for many school issues. It also broadens my knowledge and understanding of the Canadian school culture, which will eventually help me take more appropriate ways to raise my child.

In regards to her reasons for participating in the parent council, MF12 stated: 
My son is a little bit slow in learning. So I pay close attention to what is happening in school. As an immigrant parent, I have realized that Canadian school system is different from China. I hope the school and parents can better understand each other and I want my voice to be heard.

For the rest of ten families, four knew the function of parent council but never joined it, another four had heard about it but were not sure of its exact function, and two had never heard about it. The researchers explained the function of parent council to the parents who had no knowledge about it during the interviews. When being asked whether they wanted to join in this organization, these ten families provided a negative response. They believed that it was the school's responsibility to make decisions on school issues and parents should just follow the school's decision rather than voice their own opinions. In this regard, FF1 stated, "I trust the school. As a parent, we try our best to support the decision the school makes." MF10 said:

We are not familiar with the Canadian school system. In China, schools do not ask parents to engage in school governance. It is the school's responsibility to make decisions and tell us what to do. What parents should do is to follow school decisions and to help our children at home.

\section{Limitations for School Involvement}

Although all participants got involved in some types of school-based activities, they remarked that they usually did not do so if they were not invited by school teachers. They provided several reasons for limited school involvement: lack of time, language barriers, unfamiliarity with the Canadian school system, and different cultural values.

The lack of time was the most commonly cited reason. Apparently, school activities took place during weekdays when many Chinese parents either were at work or attended university classes. At the time of this study, FF8 just found a position after years of searching for a job. He said:

It is very difficult to find a job now...there is a lot of pressure at work. As a minority here, I have to work very hard and perform much better than mainstream people so that I can keep my job. I really do not have time [for school involvement].

Being a university student, MF2 said, "I am very busy with my university courses. There are many reading and writing assignments. I do not have enough time to attend school activities except for the parent-teacher conference." As a labour worker, MF5 expressed a similar point:

I do labour work for 10 hours each day. When I return home, I am exhausted but unfortunately have to do housework. I really have no energy to attend my daughter's school events. If I ask for a leave from my work, I will lose money. As a new immigrant family, seven or eight dollars are important to my family. I need the time to earn a living.

Language barrier is another reason that prevented some Chinese immigrant parents from getting involved in school-based activities. MF1, a home-maker, talked about her intention to 
volunteer in school field trip: "I have time, but my English is not good. I would volunteer only when I knew there were some Chinese children attending the field trip. So, I can offer help in my mother tongue." This holds especially true for the recently arrived parents. FF2 has been in Canada for 4 years. He said, "My English is not good. My wife talks with the teacher during the parent-teacher conference. Although her English is not very good either, she is a university student after all. She is better than me." MF5 has been in Canada for 3 years. She explained:

My English is not good. I do not completely understand what the teacher talks about during the parent-teacher conference. So, I just listen to my husband talking with the teacher. If my husband cannot go for the parent-teacher conference, I do not think I would like to go.

The unfamiliarity with the Canadian school system was reported as additional reason that blocked participants getting involved in school-based activities. As FF5 remarked:

In China, parents are not required to physically participate as volunteers, or as fundraisers. What parents do is to accompany the child doing homework, provide supplementary exercises, and buy whatever benefits the child's leaning. In Canada, the school system is different. I don't go to school that often. I am not sure what I should say and do, and what I shouldn't. I am afraid that I might get into trouble by saying or doing some things incorrectly.

MF3 echoed the similar concerns: "I do not often get involved in school activities although I would like to. I am not familiar with the Canadian school culture. I do not know how to do it in a proper way." MF4, who is one of the two mothers attending school parent council meetings, provided a good explanation about parents' lack of involvement in parent council:

I do not see other Chinese immigrant parents attending parent council meeting. They are not aware of their rights. This may be influenced by Chinese culture. China is a highly hierarchical country. In China, someone above you makes the decision. At work, you obey the boss. In school, you obey the teacher. Growing up in such a culture, Chinese parents become used to following the rules but not providing suggestions or expressing opinions.

Some parents (F2, F7, and F10) maintained that they trust teachers would take care of their children well so that they wouldn't go to school if they were not invited. FF2 expressed, "I seldom go to school to talk with teachers without invitation. We Chinese highly respect and trust the teacher. I believe the teacher would take care of my daughter very well." Parents (F7 and F10) also expressed that it was unnecessary to go to school often if their child was good at academics. FF10 commented:

We do not think we need to go to school that often. My daughter's average score is over 90. She is doing very well in reading and math. You know, in China, only when a child makes trouble or is not good at academics, the teacher asks the parents to visit the school. 


\section{Discussion}

All participating parents in this study got involved in some kinds of school-based activities. These activities included parent-teacher conferences, school fundraising, and attendance of children's school performances. A few participants who were home makers sometimes volunteered for school fieldtrips. Two participants joined parent councils.

Participants acknowledged the importance of parental school involvement. They believed that their involvement in school activities would keep them updated about their children's school performance, provide them opportunity to learn about the school and teachers' requirements, and inform their ways of parenting at home. Although parents are not expected to participate in school fundraising activities nor volunteer in fieldtrips in China, some participants made an effort to take part in these school activities to familiar themselves with the Canadian school system as best as they can.

Chinese people highly value education since education is seen as a means for social mobility in the history and present of China ( $\mathrm{Li}, 2001)$. This viewpoint of education does not go away after they move to Canada. This cultural inertia is actually reinforced and amplified by their immigrant life experience. As Table 1 indicates, a majority of participants had to receive reeducation in Canadian post-secondary institutions to find a job in spite of their education background and work experiences in China. For example, the couple of Family 3 both have a bachelor's degree in science and were software engineers in China before moving to Canada. After spending one year but failing to find a job in Canada, the husband had to obtain a Master's degree in computer science from a Canadian university. At the time of being interviewed, he had just been offered a job as a computer technician in a private company. His wife was still a nursing student. Such experience may lead participants to believe that education is the best way to overcome barriers and compensate for anticipated discrimination in the job market as Kao (1995) reposted. Therefore, they usually have high expectations of their children's education. This explains why all participants reported that children's academic performance was the greatest concern at the teacher-parent conference.

Past studies (Amatea, Smith-Adcock, \& Villares, 2006; Epstein, 1994; Fuligni, 1995; Muller, 1995) have documented that some mainstream parents tend to get actively involved in school activities even without schoolteachers' invitation. They like to take part in school decision-making processes, governance, and advocacy. In a contrast, this study indicates that most Chinese participants do not actively get involved in school activities if they do not receive invitation from the school or teachers. The majority of participants reported no interest and action in getting involved in school decision-making processes and governance. This lack of involvement can find an explanation from the following aspects: socioeconomic status, language barrier, and cultural differences.

\section{Socioeconomic Status}

Studies have identified a correlation between parents' Socioeconomic Status (SES) and their involvement (Benson \& Martin, 2003; Inaba et al., 2005; Shumow \& Harris, 2000). For instance, in a study exploring the correlation between parents' school involvement and their work status and family income, Benson and Martin (2003) found that parents holding low SES participate less in the schools than their higher SES counterparts due to inflexible work schedules, the need to take more jobs, and/or tiredness from work. This applied to the Chinese immigrants as well. In 
our study, a majority of participants who were most infrequent in school involvement were from low income and labour work families. Some of them had to have multiple jobs to support their families. They stated that when they returned home they were very tired and had no time and energy to participate in their children's school activities although they wanted to.

\section{Language Barrier}

Besides the socioeconomic status, language barrier is another factor that has impact on parental school involvement. The real and perceived low English language proficiency hinders some parents from communicating with school and leads parents to be less involved in their children's school activities. This finding is consistence with Mapp's (2003) study which states parents who speak languages other than English may experience fewer opportunities to volunteer in the schools. It is also consistent with Constantino, Cui and Faltis' (1995) study of the influence of the language barrier on Chinese parental involvement in schools. Their study indicates that the language barrier hinders Chinese immigrant parents from communicating with their children's school teachers.

\section{Cultural Differences}

Epstein and Dauber(1991) state that white middle-class teachers may value and reward independence and assume that parents will involve themselves in the school activities of their children. But other cultures may view it as rude for parents to go to school without invitation. Thus, parents' less involved in school cannot be universally understood as an indicator of less interest in their children's education. In the Chinese culture, teachers and parents are expected to play different roles with respect to children's education ( $\mathrm{Gu}, 2008$; Huntsinger \& Jose, 2009). Parents are responsible for their children's behaviours at home while teachers are expected to be responsible for student's learning and behaviours at the school. Only when a child causes trouble such as a violation of school rules, or is in need of extra help in academic work, are parents contacted. If the students perform well in school, both the teacher and parents do not feel the need for parents to go to the school.

A Chinese proverb, shi tu ru fu zi 师徒如父子(master and apprentice are similar to father and son), illustrate the Chinese teacher's authority role in education. Teachers are not only considered as experts in education content, but have the power to discipline students. Therefore, there exists a hidden hierarchical relationship between teachers and parents in children's education in China. In addition, the long history of feudalism in China together with Confucius' philosophy on social structure has a profound influence on Chinese people's respect for the authority (Bush \& Qiang, 2002). Therefore, although Canadian school culture encourages a closer parent-school relationship nurtured by parents spending more time in school (Hill \& Taylor, 2004), the majority of Chinese immigrant parents may not realize or grasp this opportunity. They tend to take a passive role in getting involved in school and allowed one-way communication to take place. In other words, Chinese immigrant parents tend to adapt and adjust themselves to meet the needs of the school rather than to voice their opinions regarding their children's education. This is particularly true for new Chinese immigrants who are less familiar with the North American culture and school system. In this study, participants who live in Canada less than five years were not sure about what to say and whom to talk with. They were afraid that they may offend the teachers if they asked or said something inappropriate. They 
choose to remain silent. Chen muo shi jin 沉默是金 (silence is gold) is actually a life philosophy of Chinese culture, which is tied with Confucius' philosophy zhong yong zhi dao 中庸之道 (the middle way). It warns people that when you do not know the appropriate thing to say, do not say anything. This life doctrine guides many Chinese people's behaviour in a social context.

\section{Conclusion and Implications}

In this study, all participants shared a belief that their school involvement would benefit their children's education. In other words, they did see their roles in their children's education as beneficial. However, some participants reported low self-efficacy for actively getting involved in school-based activities due to the language barrier. This finding supports the model of Walker et al. (2005) in regard to the significance of parents' motivational beliefs. The main school-based activities that participants were involved in included attending parent-teacher conferences, volunteering on field trips, fundraising, and attending school concerts and sports events. For these events, the parents often received invitations from schools or teachers. This finding supports Walker et al.'s model regarding the significance of parents' perceptions of invitations for involvement from others: schools, children, and teachers. As far as the factor of parent's perceived life context described in this model, this study also provides evidence. In this study, the lack of time and energy were reported as among the major reasons that impeded Chinese immigrant parents' involvement in their children's education, particularly for those participants who came to Canada lately. In addition, their inadequate knowledge about the English language and Canadian culture kept them from getting actively involved in many school-based activities. They felt intimidated to talk to teachers since they do not know what they can say and what not given their unfamiliarity with Canadian schools.

This study not only provides evidence to support the model of Walker et al. (2005), but also enriches this model with a cultural dimension. By exploring the perspectives and practices of a group of Chinese immigrant parents' involvement in their children's school education, this study demonstrates that in addition to the three categories of factors portrayed in Walker et al.'s model, participants' original cultural values play an important role in defying how they get involved in their children's school education. The authoritative figure that teachers are entitled in the Chinese culture stops Chinese immigrant parents from actively voicing their views or concerns. Chinese parents' emphasis on academics assures that their most significant concern during the teacher-parent conference is their children's academic records.

The findings of this study have some practical implications for the school's effort to involve immigrant parents. Since time is a challenge for many immigrant parents due to their work or study schedules. Teachers can use various methods to keep in touch with parents. Besides arranging face-to-face meetings, teachers can use emails, written notes, as well as phone calls to exchange information with parents on their children's school performances, school events and activities, and listen to the parents' concerns, suggestions, and expectations about their children's education. In order to help new immigrant parents to resolve the language barrier, school can provide translators with a bilingual background (who know English as a second language). Schools could also create opportunities for parents to better understand the Canadian school system and its expectations for children and parents by hosting workshops with interpreters and distributing brochures in different languages. It will be a good idea as well for teachers to learn the essence of different cultural values in educating children so that they can be more effective and proactive in communicating with immigrant parents. Considering the cultural 
barrier Chinese parents have for school involvement, school can organize information sessions to explicitly express its willingness to hear immigrant parents' voices about the school's curriculum and administration and as well to education them about their rights to get involved.

All participants in this study are professional Chinese immigrant parents with strong education backgrounds. Therefore, this study cannot represent other Chinese immigrants who are less educated in Windsor, Canada. More research is necessary to cover the Chinese immigrants with less education although they only represent a very small portion of recent Chinese immigrants. Future study can also include school teachers and immigrant children, which will provide different perspectives on immigrants' parental involvement in their children's school education. 


\section{References}

Adams, K. S., \& Christenson, S. L. (2000). Trust and the family-school relationship: An examination of parent-teacher differences in elementary and secondary grades. Journal of School Psychology, 38, 447-497.

Amatea, E. S., Smith-Adcock, S., \& Villares, E. (2006). From family deficit to family strength: Viewing families' contribution to children's learning from a family resilience perspective. Professional School Counselling, 9, 177-188.

Balli, S. J., Demo, D. H., \& Wedman, J. F. (1998). Family involvement with children's homework: An intervention in the middle grades. Family Relations, 47, 149-157.

Benson, F., \& Martin, S. (2003). Organizing successful parent involvement in urban schools. Child Study Journal, 33(3), 187-193.

Berg, B. L. (2007). Qualitative research methods for the social sciences (6 $6^{\text {th }}$ ed.). Boston: Pearson and Allyn and Bacon.

Brough, J., \& Irvin, J. (2001). Parental involvement supports academic improvement among middle schoolers. Middle School Journal, 32(5), 56-59.

Bush, T., \& Qiang, H. (2002). Leadership and culture in Chinese education. In A. Walker \& C. Dimmock (Eds.). School Leadership and Administration: Adopting a Cultural Perspective (pp.173-186). NY: RoutledgeFalmer.

Citizenship and Immigration Canada. (2006). The Monitor. Retrieved from http://www.cic.gc.ca/english/monitor/issue13/05-overview.html

Coleman, P. (1998). Parent, student and teacher collaboration: The power of three. California: Corwin Press, Inc.

Commins, N. L. (1992) Parents and public schools: the experiences of four Mexican immigrant families. Equity and Choice, 8, 40-45.

Constantino, R., Cui, L., \& Faltis, C. (1995). Chinese parental involvement: Reaching new levels. Equity \& Excellence in Education, 28(2), 46-50.

Creswell, J. W. (2007). Qualitative inquiry and research design: Choosing among five traditions $\left(2^{\text {nd }}\right.$ ed). Thousand Oaks, CA: Sage.

Creswell, J. W. (2008). Educational research: Planning, conducting, and evaluating quantitative and qualitative research ( ${ }^{\text {rd }}$ ed.). Upper Saddle River, NJ: Pearson.

Denzin, N. K., \& Lincoln,Y. S. (2000). Introduction: The discipline and practice of qualitative research. In N. K. Denzin and Y. S. Lincoln (Eds.). Handbook of Qualitative Research $\left(2^{\text {nd }}\right.$ ed. $)$, London: Sage.

Desforges, C., \& Abouchaar, A. (2003). The impact of parental involvement, parental support and family education on pupil achievements and adjustments: A literature review, Research Report 443. London: DfES.

Dyson, L. L. (2001). Home-school communication and expectations of recent Chinese immigrants. Canadian Journal of Education, 26(4), 455-476. 
Entwisle, D., \& Alexander, K. (1995). A parent's economic shadow: Family structure versus family resources as influences on early school achievement. Journal of Marriage and Family, 57(2), 399-409.

Epstein, J. L. (1995). School-family-community partnerships: Caring for the children we share. Phi Delta Kappan, 76, 701-712.

Epstein, S. (1994). Integration of the cognitive and the psychodynamic unconscious. American Psychologist, 49, 709-724.

Epstein, J. L., \& Dauber, S. (1991). School programs and teacher practices of parent involvement in inner-city elementary and middle schools. The Elementary School Journal, 91, 279289.

Fan, X., \& Chen, M. (2001). Parental involvement and students' academic achievement: A metaanalysis. Educational Psychology Review, 13(1), 1-22.

Fuligni, A. J. (1995). Effects of parental involvement and family context on the academic achievement of third-and fourth-grade children. Unpublished doctoral dissertation, University of Michigan.

Grolnick, W, S., Kurowski, C. O., Dunlap, K. G., \& Hevey, C. (2000), Parental resources and the transition to junior high. Journal of Research on Adolescence, 10(4), 465-488.

Gu, W. (2008). New horizons and challenges in China's public schools for parent involvement. Education, 128(4), 570-578.

Guo, S., \& DeVoretz, D. J. (2006). The changing face of Chinese immigrants in Canada. Journal of International Migration and Integration, 7(3), 275-300.

Hill, N. E., \& Taylor, L. C. (2004). Parental school involvement and children's academic achievement. Current Directions in Psychological Science, 13, 161-164.

Ho, E. S. C., \& Willms, J. D. (1996). The effects of parental involvement on eighth grade achievement. Sociology of Education, 69, 126-141.

Hoover-Dempsey, K. V., \& Sandler, H. (1995). Parental involvement in children's education: Why does it make a difference? Teachers College Record, 97(2), 310-331.

Hoover-Dempsey, K. V., \& Sandler, H. (1997). Why do parents become involved in their children's education? Review of Educational Research, 67(1), 3-42.

Huntsinger, C. S., \& Jose, P. E. (2009). Relations among parental acceptance and control and children's social adjustment in Chinese American and European American families. Journal of Family Psychology, 23, 321-330.

Inaba, A., Thoits, P. A., Ueno, K., Gove, W. R., Evenson, R. J., \& Sloan, M. (2005). Depression in the United States and Japan: Gender, marital status, and SES patterns. Social Science \& Medicine, 61, 2280-2292.

Jeynes, W. H. (2003). A Meta-analysis: The effects of parental involvement on minority children's academic achievement. Education \& Urban Society, 35(2), 202-218. 
Jeynes, W. H. (2005a ). A meta-analysis of the relation of parental involvement to urban elementary school student academic achievements. Urban Education, 40(3), 237-269.

Jeynes, W. H. (2005b). Effects of parental involvement on the academic achievement of adolescents. Marriage and Family Review, 37, 99-116.

Jeynes, W. H. (2007). The relationship between parental involvement and urban secondary school student academic achievement. Urban Education, 42, 82-110.

John-Steiner, V., \& Mahn, H. (1996). socio-cultural approaches to learning and development: a Vygotskian framework. Educational Psychologist, 3(3), 191-206.

Juang, L. P., \& Silbereisen, R. K. (2002). The relationship between adolescent academic capability beliefs, parenting, and school grades. Journal of Adolescence, 25, 3-18.

Kao, G. (1995). Asian Americans as model minorities? A look at their academic performance. American Journal of Education, 103(2), 121-159.

Kao, G., \& Tienda, M. (1998). Educational aspirations of minority youth. American Journal of Education, 106 (3), 349-384.

Lareau, A. (1987). Social class differences in family-school relationships: The importance of cultural capital. Sociology of Education, 60, 73-85.

Lee, J., \& Bowen, N. (2006). Parent involvement, cultural capital, and the achievement gap among elementary school children. American Educational Research Journal, 43(2), 193218.

Li, D. (2005). Attitudes, motivations and identities in learning Chinese as a heritage. Paper presented at the $14^{\text {th }}$ World Congress of Applied Linguistics, Madison, WI.

Li, J. (2001). Expectations of Chinese immigrant parents for their children's education: The interplay of Chinese tradition and the Canadian context. Canadian Journal of Education, 26, 477-494.

Louie, V. (2001). Parents' aspirations and investment: The role of social class in the educational experiences of 1.5- and second-generation Chinese Americans. Harvard Educational Review, 71(3), 438-474.

Mapp, K. L. (2003). Having their say: Parents describe why and how they are engaged in children's learning. School Community Journal, 13(1), 35-64.

Mau, W. (1997). Parental influences on the high school students' academic achievement: A comparison of Asian immigrants, Asian Americans, and White Americans. Psychology in the Schools, 34, 267-277.

Maxwell, J. A. (2004). Qualitative research design: An interactive approach ( $2^{\text {nd }} \mathrm{ed}$.). Thousand Oaks: Sage.

McNeal, R. B. (1999). Parental involvement as social capital: Differential effectiveness on science achievement, truancy, and dropping out. Social Forces, 78, 117-144.

Muller, C. (1995). Maternal employment, parental involvement, and mathematics achievement among adolescents. Journal of Marriage and the Family, 57, 85-100. 
Patton, M. Q. (2002). Qualitative evaluation and research methods $\left(3^{\text {rd }}\right.$ ed). Thousand Oaks, CA: Sage.

Perna, L. W. (2004). Impact of student aid program design, operations, and marketing on the formation of family college-going plans and resulting college-going behaviors of potential students. Boston: The Education Resources Institute.

Rogoff, B. (1990) Apprenticeship in thinking: Cognitive development in social context. Oxford: Oxford University Press.

Rogoff, B. (2003). The cultural nature of human development. New York: Oxford University Press.

Rogoff, B., \& Angelillo, C. (2002).Investigating the coordinated functioning of multifaceted cultural practices in human development. Human Development, 45, 211-225.

Rubin, H. J., \& Rubin, I. S. (1995). Qualitative interviewing: The art of hearing data. Thousand Oaks, CA: Sage.

Schwandt, T. A. (2001). Dictionary of qualitative inquiry ( $2^{\text {nd }}$ ed.). Thousand Oaks, CA: Sage.

Sheldon, S., \& Epstein, J. (2001). Improving student behaviour and discipline with family and community involvement. John Hopkins University: Centre for Research on the Education of Students Placed at Risk.

Shumow, L., \& Harris, W. (2000). Teachers' thinking about home-school relations in lowincome urban communities. School Community Journal, 10(1), 9-24.

Simon, B. S. (2004). High school outreach and family involvement. Social Psychology of Education, 7, 185-209.

Siu, S. F. (1994). Taking no chances: A profile of a Chinese-American family's support for school success. Equity and Choice, 10(2), 23-32.

Sputa, C. L., \& Paulson, S. E. (1995). Birth order and family size: Influences on adolescents' achievement and related parenting behaviours. Psychological Reports, 76, 43-51.

Statistics Canada (2006). 2006 Community Profiles. Retrieved from http://www12.statcan.ca/census-recensement/2006/dp-pd/prof/92-591/index.cfm?Lang=E.

Steinberg, L., Lamborn, S. D., Dornbusch, S. M., \& Darling, N. (1992). Impact of parenting practices on adolescent achievement: Authoritative parenting, school involvement, and encouragement to succeed. Child Development, 63, 1266-1281.

Strauss, A., \& Corbin, J. (1990). Basics of qualitative research: Grounded theory procedures and techniques. London: Sage.

Taub, D. J. (2008). Exploring the impact of parental involvement on student development. New Directions for Student Services, 122, 15-28.

Taylor, R. D., \& Lopez, E. I. (2005). Family management practice, school achievement and problem behavior in African American adolescents: Mediating process. Journal of Applied Development Psychology, 26, 39-49. 
Vygotsky, L. S. (1987). Thinking and speech. In R. Rieber \& A. Carton (Eds.), Collected works, Volume 1 (pp. 39-285). New York: Plenum.

Walker, J. M. T., Wikins, A. S., Dallaire, J. R., Sandle, R. H. M., \& Hoover-Dempsey, H. (2005) Parental Involvement: Model Revision through Scale Development. The Elementary School Journal, 106(2), 85-104.

Wertsch, J. V., \& Kanner, B. G. (1992). A sociocultural approach to intellectual development. In R. J. Sternberg and C.A. Berg (Eds.), Intellectual Development (pp. 328-349). New York: Cambridge University Press.

Zellman, G. L., \& Waterman, J.M. (1998). Understanding the impact of parent school involvement on children's educational outcomes. The Journal of Educational Research, 91(6), 370-380.

Zhou, M. (2000). Social capital in Chinatown: The role of community-based organizations and families in the adaptation of the younger generation. In M. Zhou \& J. Gatewood (Eds.), Contemporary Asian America: A multidisciplinary reader. New York: New York University Press. 